\author{
Johnson D. Ogunlusi • Lawrence M. Oginni • \\ Innocent C. Ikem
}

\title{
Compartmental pressure in adults with tibial fracture
}

Received: 21 November 2004 / Accepted: 6 December 2004 / Published online: 1 February 2005

(C) Springer-Verlag 2005

\begin{abstract}
Acute compartment syndrome is associated with tibial fractures and failure to diagnose it leads to grave consequences. This study was conceived with the aim of determining the intra-compartmental pressure in adults with closed tibial fractures and intended to provide early diagnosis of acute compartment syndrome. The Whitesides injection method was used, using hospital-available materials. The intra-compartmental pressure in the anterior and deep posterior compartments of 52 patients with closed tibial fractures was measured at presentation and 4 hourly for $24 \mathrm{~h}$. In three patients, the pressure was very high, and the differential pressure (i.e. the difference between the diastolic blood pressure and the intra-compartmental pressure) was greater than $30 \mathrm{mmHg}$, which was diagnostic of acute compartment syndrome. They were all treated by fasciotomy. It is concluded that Whitesides method can be used to diagnose acute compartment syndrome. The apparatus is easy to set up, inexpensive and therefore ideal for use in our environment where sophisticated devices of tissue pressure measurement are not available.
\end{abstract}

Résumé Le syndrome compartimental aigu, ou syndrome de loge, est associé avec les fractures tibiales et l'absence de son diagnostic a des conséquences graves. Cette étude a pour but de déterminer la tension intracompartimentale chez l'adulte présentant une fracture fermée du tibia pour pouvoir diagnostiquer précocement un syndrome de loge. Les tensions intracompartimentales dans les compartiments antérieurs et postérieurs profonds de 52 malades avec une fracture tibiale fermée ont été mesurées à l'admission puis

J. D. Ogunlusi · L. M. Oginni · I. C. Ikem

Department of Orthopaedics and Traumatology, Obafemi

Awolowo University Teaching Hospitals Complex,

Ile-Ife, Nigeria

J. D. Ogunlusi $(\bowtie) \cdot$ L. M. Oginni · I. C. Ikem

Department of Orthopaedics Surgery and Traumatology,

College of Health Sciences, Obafemi Awolowo University,

Ile-Ife, Osun State, Nigeria

e-mail: gbemidare@yahoo.com

Tel.: +234-80-55336926

Fax: +234-36-230141 toutes les quatre heures pendant $24 \mathrm{~h}$. Nous avons utilisé la méthode de Whitesides avec piqûres en utilisant le matériel disponible dans l'hôpital. Chez trois malades la pression différentielle (c.-à-d. la différence entre la tension artérielle diastolique et la tension intracompartimentale) était $\leq 30$ $\mathrm{mmHg}$ ce qui diagnostique le syndrome compartimental. Tous ont été traités par fasciotomie tibiale. Nous concluons que cette méthode de Whitesides peut être utilisée pour diagnostiquer le syndrome compartimental. L'appareil est facile à installer et bon marché et il est recommandé dans notre environnement où les appareils sophistiqués ne sont pas disponibles.

\section{Introduction}

Compartmental pressure measurement has been a topic of research interest since Volkmann in 1881 described a posttraumatic muscle contracture of acute onset, which resulted from ischaemic changes of the muscle [17]. The common denominator for compartment syndrome is an elevated interstitial fluid pressure causing vascular occlusion in the compartment containing muscle [16]. Acute compartment syndrome is a limb- and, sometimes, a lifethreatening surgical emergency that must be diagnosed and managed promptly.

The diagnosis of acute compartment syndrome calls for a high index of suspicion [7]. The symptoms and signs, which are usually subjective and cannot be determined unless the patient is co-operative and alert, may sometimes lead to diagnosis [8] but are often so ambiguous that a definite diagnosis cannot be made on clinical grounds alone [20]. The subjectivity of the symptoms and the equivocal nature of the signs limits the extent of clinical reliability, hence the need to accurately measure the intracompartmental pressure. Many methods have been used to assess the intra-compartmental pressure-from the simple Whitesides injection to complex magnetic resonance imaging $[5,16,20]$.

In recent times, there has been an increase in the frequency of road traffic accidents in Nigeria associated with 
increased tibial fractures [1]. The average practitioner, who is unfamiliar with the diagnosis and management of the syndrome, would miss some of the cases. It has been recommended that when the equipment is available, all patients with tibial fractures should have continuous compartmental pressure monitoring to minimise the incidence of acute compartment syndrome [10]. Compartmental pressure can be measured by the Whitesides injection technique; however, its limitation is that it gives a reading at one instant and is therefore unsuitable for continuous intra-compartmental pressure monitoring. Seventeen percent of practising orthopaedic trauma consultants in Scotland applied this method to monitor the pressure in patients vulnerable to compartment syndrome in a study done by Vassalos et al. [21]. The beauty of the Whitesides injection technique is that it uses materials that are easily available in most hospitals.

Such work has not been done here; thus, this study was set up to measure the intra-compartmental pressure in closed tibial fractures in order to detect acute compartment syndrome.

\section{Materials and methods}

This was a prospective, hospital-based study of the measurement of compartmental pressure in tibial fracture in adults who presented at the Wesley Guild Hospital (WGH), Ilesa. The hospital is located in Ilesa within a major road network linking various urban centres in the south-western, northern and eastern parts of Nigeria. The hospital serves part of Osun State and as referral centre to three neighbouring states.

Consecutive patients with closed tibial fractures who were over 16 years old presenting at the accident and emergency department of WGH, Ilesa over 16 consecutive months were recruited. Patients with open fractures and children were excluded. A total of 52 patients fulfilled the inclusion criteria. Approval was obtained from the Obafemi Awolowo University Teaching Hospitals Complex, Research and Ethical Committee. Written informed consent was obtained from patients for the measurement of compartmental pressure of both anterior and deep-posterior compartments of the leg in the 52 patients.

A full evaluation and resuscitation of the patients was made. Pulse rate, respiratory rate and blood pressure were recorded. Compartmental pressure was measured at the fracture site as suggested by Heckman et al. [8], i.e. within $5 \mathrm{~cm}$ of the fracture site, and the Whitesides injection method was used $[17,20]$. The fracture site was identified by a combination of clinical and radiological findings. The site was marked with indelible ink, cleaned and prepared aseptically using chlorhexidine solution and methylated spirit. Measurement was done at presentation for both anterior and deep-posterior compartments of the legs and then 4 hourly for another six readings. The fracture was reduced, and a back-slab plaster of Paris (POP) applied to prevent movement at the fracture site.
Table 1 Age distribution of the study group

\begin{tabular}{ll}
\hline Age in years & Number \\
\hline $16-30$ & 17 \\
$31-45$ & 14 \\
$46-60$ & 10 \\
$61-75$ & 6 \\
$76-90$ & 5 \\
Total & 52 \\
\hline
\end{tabular}

\section{Results}

Fifty-two of the 151 patients with tibial fractures satisfied the criteria for inclusion in the study. Thirty-six were male and 16 were female. Their ages ranged from 16 to 90 years with a mean of $42.9(\mathrm{SD} \pm 20.6)$ (Table 1).

The left leg was involved in 29 patients and the right leg in 23. Table 2 shows the three patients who developed acute compartment syndrome. The range of differential pressure for anterior compartment in the remaining 49 patients was $36-94 \mathrm{mmHg}$ and the mean $64.5( \pm 11.4)$ $\mathrm{mmHg}$ while for the deep posterior compartment they were 33-92 and $64.9( \pm 11.6) \mathrm{mmHg}$ respectively.

\section{Discussion}

Closed tibial fracture is one of the conditions most frequently associated with development of compartment syndrome [3, 19]. Approximately $40 \%$ of all acute compartment syndromes occur after fractures of the tibial shaft $[5,11]$. The young adult with a tibial fracture is at higher risk than the older age group because of the relative large muscle volume in the young patient $[14,19]$. There are four compartments in the leg, namely, anterior, lateral, superficial posterior and deep posterior. Each contains compressible neurovascular structures and muscles [13]. In the leg, acute compartment syndrome occurs mainly in the anterior and deep-posterior compartments [7, 12].

Acute compartment syndrome can be limb- and lifethreatening and if missed results in high morbidity and mortality. In a study of malpractice costs associated with missed diagnosis in Minneapolis, MN, USA, the average indemnity was nearly $\$ 280,000$. [19]. Measurement of intra-compartmental pressure makes positive diagnosis of acute compartment syndrome possible. Some consider that routine pressure monitoring is unnecessary because of the infrequent occurrence of acute compartment syndrome. They also claim that it is unnecessary because the need for fasciotomy is usually clinically apparent [18]. Despite these assertions by Rollins et al., five of their patients had the sequelae of acute compartment syndrome because the diagnosis had been delayed. The results of inadequate treatment of compartment syndrome are never satisfactory, and treatment of the complications of the syndrome is unrewarding. Prevention of complications by early diagnosis and treatment is the better option $[7,9]$.

In this study, the male-to-female ratio was $2.3: 1$, and the age group maximally affected was between 16 and 45 years, 
Table 2 Symptomatic cases. $S / N$ Serial number, D/Posterior deep posterior compartment of the leg

\begin{tabular}{|c|c|c|c|c|c|c|c|c|c|}
\hline \multirow[t]{2}{*}{$\mathrm{S} / \mathrm{N}$} & \multirow[t]{2}{*}{ Age } & \multirow[t]{2}{*}{ Gender } & \multirow{2}{*}{$\begin{array}{l}\text { Time of } \\
\text { diagnosis } \\
\text { (h) }\end{array}$} & \multirow{2}{*}{$\begin{array}{l}\text { Interval } \\
\text { between } \\
\text { injury and } \\
\text { fasciotomy } \\
\text { (h) }\end{array}$} & \multirow[t]{2}{*}{$\begin{array}{l}\text { Tibia fracture, } \\
\text { fibula fracture }\end{array}$} & \multirow[t]{2}{*}{ Symptoms and signs } & \multirow{2}{*}{$\begin{array}{l}\text { Diastolic } \\
\text { BP } \\
(\mathrm{mmHg})\end{array}$} & \multicolumn{2}{|c|}{$\begin{array}{l}\text { Compartmental } \\
\text { pressure }(\mathrm{mmHg})\end{array}$} \\
\hline & & & & & & & & Anterior & $\begin{array}{l}\text { D/ } \\
\text { Posterior }\end{array}$ \\
\hline A & 16 & M & 5 & 5.5 & $\begin{array}{l}\text { Spiral fracture of the right } \\
\text { tibia at junction of the } \\
\text { upper two thirds, and } \\
\text { fibula fracture at above } \\
\text { level with lateral } \\
\text { displacement of } \\
\text { the bones }\end{array}$ & $\begin{array}{l}\text { Severe pain at fracture } \\
\text { site. Reduced dorsalis } \\
\text { pedis. Muscle under } \\
\text { tension but pink at } \\
\text { fasciotomy }\end{array}$ & 70 & 20 & 40 \\
\hline B & 18 & M & 36 & 37 & $\begin{array}{l}\text { Comminuted fracture } \\
\text { of upper one third } \\
\text { of right tibia with } \\
\text { intact fibula }\end{array}$ & $\begin{array}{l}\text { Pain at fracture site, } \\
\text { reduced dorsalis pedis } \\
\text { paraesthesia of the first } \\
\text { web space. Tension at } \\
\text { fracture site. Muscle } \\
\text { under tension at fasciotomy. } \\
\text { Dusky and poor contractility } \\
\text { of the muscle }\end{array}$ & 60 & 34 & 8 \\
\hline $\mathrm{C}$ & 45 & M & 5.5 & 6 & $\begin{array}{l}\text { Severely comminuted } \\
\text { fracture of the proximal } \\
\text { one half of the left tibia. } \\
\text { Transverse fracture of the } \\
\text { fibula at the junction of } \\
\text { the upper one third and } \\
\text { the lower two thirds, and } \\
\text { lateral fibula displacement. } \\
\text { Fracture of the fibula neck }\end{array}$ & $\begin{array}{l}\text { Severe pain at the fracture } \\
\text { site, blisters at the fracture } \\
\text { site, paraesthesia on the } \\
\text { dorsum of the foot. Severe } \\
\text { pain at the calf on passive } \\
\text { dorsiflexion. Normal volume } \\
\text { of dorsalis pedis. Muscle } \\
\text { under severe tension at } \\
\text { fasciotomy, dusky, poor } \\
\text { contractility }\end{array}$ & 80 & 55 & 45 \\
\hline
\end{tabular}

which constituted 31 of the 52 patients. This is the active age group in which there will be loss of function and longterm productivity in patients who would otherwise have contributed to the countries' workforce. Twenty-four of the patients presented in the hospital within $6 \mathrm{~h}$ of injury and the remainder after $6 \mathrm{~h}$. Three patients out of the 52 developed acute compartment syndrome. Two presented and were diagnosed within $6 \mathrm{~h}$ of injury and one at $36 \mathrm{~h}$ post-injury (Table 2). All were male, and their ages were 16, 18 and 45 years (patients A, B and C), respectively. Motorcycle accidents were the cause of the tibial fractures in two and football in one. The relatively large muscle volume in the young and the high-energy injuries causing the fractures will have promoted the development of the syndrome in these three patients $[10,19]$. Patient $C$ developed blisters within $5 \mathrm{~h}$, which in the absence of thermal injury might suggest high intra-compartmental pressure. Dorsalis pedis pulse was reduced in volume in patient $\mathrm{A}$ and $\mathrm{B}$ but was normal and full in patient $C$ who had a very high intracompartmental pressure. This supports the finding that the pressure is rarely high enough to occlude the major blood vessels, and thus the presence of the peripheral pulses does not exclude diagnosis of compartment syndrome [2, 15].
Radiological findings of the three patients showed that the fractures were at the upper two thirds of the tibia in all the three and were comminuted in patients B and C. Patients A and $\mathrm{C}$ had displaced fibular fractures. Fibular fracture with displacement has been associated with disruption of the inter-osseous membrane and greater soft tissue injury, which can lead to increased compartmental pressure [4]. This might explain the development of acute compartment syndrome in patients A and C. Patient B had a comminuted fracture of the proximal tibia with an intact fibula; the posterior compartmental pressure was normal $(8 \mathrm{mmHg})$ while the anterior was $34 \mathrm{mmHg}$. The intact fibula and hence, most likely, the intact inter-osseous membrane would account for this finding.

Whitesides' recommendation of differential pressure (i.e. the difference between the diastolic blood pressure and the intra-compartmental pressure) of $>30 \mathrm{mmHg}$ as the threshold for fasciotomy was used to identify the three patients that needed fasciotomy. The deep-posterior compartment of patient $\mathrm{A}$ and anterior compartment of patients $\mathrm{B}$ and $\mathrm{C}$ had differential pressures $>30 \mathrm{mmHg}$. The patients had all four compartments of the leg decompressed by two incisionsmedial and lateral - as recommended by Mubarak and 
Owen [14]. Four compartments were decompressed as recommended by Tornetta and Templeman [19] because hyperaemia may precipitate increased pressure in the adjacent compartments. Elliot and Johnstone [5] also supported decompression of all four compartments in order not to miss the syndrome in the compartments where pressure was not measured.

At follow up, patients $\mathrm{A}$ and $\mathrm{C}$, who were diagnosed and managed with fasciotomy within $6 \mathrm{~h}$ of injury, had regained neurovascular function by 6 weeks post-injury. Patient B, who presented $36 \mathrm{~h}$ after injury, still had an area of hypoaesthesia involving a wedge-shaped area on the dorsum of the right foot proximal to the base of the first and second toes at 4 months post-injury. The mild neurological deficit might be because although the compartment syndrome did not develop early, it may have developed more than $6 \mathrm{~h}$ before presentation. The remaining 49 patients with closed tibial fractures had no sequelae to suggest the development of compartment syndrome. Delayed presentation could have grievous consequences; Finkelstein et al. [6] in Toronto, Canada, in 1996 reported nine lower-limb fasciotomies in five patients after a delay of more than $35 \mathrm{~h}$ (due to transport delay or misdiagnosis) - one died of multiple organ failure and septicaemia, the other four had above-knee amputations.

The apparatus used for this study is simple, easily available in any hospital and, most importantly, inexpensive. It can be assembled within $10 \mathrm{~min}$ and thus easily used to measure compartmental pressure in patients that are considered to be at risk of developing compartment syndrome. It is concluded that Whitesides injection method of intra-compartmental pressure monitoring is of great value in the accurate diagnosis of acute compartment syndrome, especially in developing countries where sophisticated devices are not available.

\section{References}

1. Adesunkanmi ARK, Oginni LM, Oyelami OA (1998) Epidemiology of childhood injury. J Trauma 44(3):506-511

2. Ashton H (1975) The effect of increased pressure on blood flow. Clin Ortop 113:15-26
3. Cooper RR MD (1984) Skeletal muscle and muscle disorder. In: Cruess RL, Rennie WRJ (eds) Adult orthopaedic volume I. Churchill Livingstone,Edinburgh, pp 495-499

4. Delee JC, Stiehl JB (1981) Open tibia fracture with compartmental syndrome. Clin Ortop 160:175-184

5. Elliott KG, Johnstone AJ (2003) Diagnosing acute compartment syndrome? J Bone Joint Surg Br 85(5):625-632

6. Finkelstein JA, Hunter GA, Hu RW (1996) The limb compartment syndrome: course after; delay fasciotomy. J Trauma 40 (3):342-344

7. Gulli B, Templeman D (1994) Compartment syndrome of the lower extremity. Orthop Clin North Am 25(4):677-684

8. Heckman MM, Whitesides TE, Grewe SR, Rooks MD (1994) Compartment pressure in association with closed tibial fractures. J Bone Joint Surg Am 76(9):1285-1292

9. McQueen MM (1999) Acute compartment syndrome in tibial fracture. Curr Orthop 13:113-121

10. McQueen MM, Chirstie J, Court-Brown CM (1996) Acute compartment syndrome in tibial diaphyseal fractures. J Bone Joint Surg Br 78(1):95-98

11. McQueen MM, Gaston P, Court-Brown CM (2000) Acute compartment syndrome who's at risk? J Bone Joint Surg Br 82:200-203

12. Moeyersoon JP, Mantens M (1992) Chronic compartmental syndrome, diagnosis and management. Acta Orthop Belg 58 (1):23-27

13. Moore KL (1992) The lower limb. In: Clinically oriented anatomy, 3rd edn. Williams and Wilkins, Baltimore, pp 443 460

14. Mubarak SJ, Owen CA (1977) Double incision fasciotomy of the leg for decompression in compartmental syndromes. J Bone Joint Surg Am 59(2):184-187

15. Mubarak SJ, Owen CA (1975) Compartmental syndrome and its relation to crush syndrome: a syndrome of disease; a review of 11 cases of prolong limb compression. Clin Ortop 113:81-89

16. Mubarak SJ, Owen CA, Hargens AR, Garetto LP, Akeson WH (1978) Acute compartment syndrome diagnosis and treatment with the aid of the wick catheter. J Bone Joint Surg Am 60 (8):1091-1095

17. Pellegrini VD Jr, Reid S, Evants CM (1996) Complication. In: Rockwood CA, Green DP, Bucholz RW, Heckman JD (eds) Fracture in adult volume 1, 4th edn. Lippincott-Raven, Philadelphia, pp 487-511

18. Rollins DL, Bernhard VM, Towene JB (1981) Fasciotomy; an appraisal of controversial issues. Arch Surg 116:1474-1481

19. Tornetta P III, Templeman D (1996) Compartment syndrome associated with tibia fracture. J Bone Joint Surg Am 78 (9):1438-1444

20. Whitesides TE Jr, Haney TC, Morimoto K, Harada K (1975) Tissue pressure measurement as a determinant for the need of fasciotomy. Clin Ortop 113:43-51

21. Vassalos A, Rana B, Patterson PRN, Grigoris P (2003) Current trends in Scottish practice. Scott Med J 48(3):82-84 